\title{
Removal of Hardened Cement Deposited on PV Panels and Its Effect on Power Generation
}

\author{
Hardeep Rajput \\ Student, School of Energy Studies, \\ SPPU \\ Vaibhav Lavhale \\ Student, School of Energy Studies, \\ SPPU
}

\author{
Sujit Patil \\ Student, School of Energy Studies, \\ SPPU \\ Jayeshkumar Pindoriya \\ Student, School of Energy Studies, \\ SPPU
}

\begin{abstract}
Urban environment effects the power generation capacity of PV plant. There is various type of matter present in urban area. Dust from a construction site can be categorized as (i) Silica dust (ii)Wood dust (iii)Low toxity dust like gypsum, limestone, dolomite. When this dust gets deposited on surface of solar panel they block sun light from reaching cells. Shading of photovoltaic panel affect energy output generation. Shading of PV panel cause hotspot and other issue. Thus decreasing the life of PV panel. For this background, the purpose of our experiment (i) Removing of hardened cement on glass at low rate possible (ii) Observing after effect of acid on $P V$ panel (iii) Observing change in PR of solar PV plant before and after cleaning The result of the experiment is increased PR of $86 \%$ and after 6 months of observation. There is no sign of damage due to use of acid for cleaning purpose.
\end{abstract}

Keywords: Anti Reflective coating(ARC), Mutric acid or Hydrochloric acid(HCl), Photovoltaic (PV), kilo-Watt hour (kWh) etc.

\section{INTRODUCTION}

Analyzing current scenario, the world energy demand is rising day-by-day. Nevertheless, the prices of fossil fuel are growing exponentially. Along with fossil fuel comes environmental problem which are rising at an alarming rate. There is a huge gap between supply and demand of energy. It is being predicted by 2040 fifty percent of energy will come from renewable source[1]. Solar energy, playing a major role in meeting future energy demand.

PV systems have a life expectancy of 25 years. To ensure that they perform at full efficiency, maintenance of plants must be done regularly.

Depending upon the type of system O\&M service differs for every PV plant. Every site has different problems hence, innovation is needed. Existing method of removing cement include use of product which are expensive. This may also require more human time to manually remove and scrub each inch of area to remove cement. This scrubbing will definitely remove ARC coating. We began by observing the site and trying out various method to clean it. A small patch had been clean with $\mathrm{HCl}$ acid and result were satisfactory without any trouble of scrubbing. Nowadays many automation tool are available in market to remove soil from panel but there is small segment present rooftop solar. The challenges are different from ground mounted solar project. Along with soil many other man-made and natural debris get deposited on module.
A. Causes of deposition
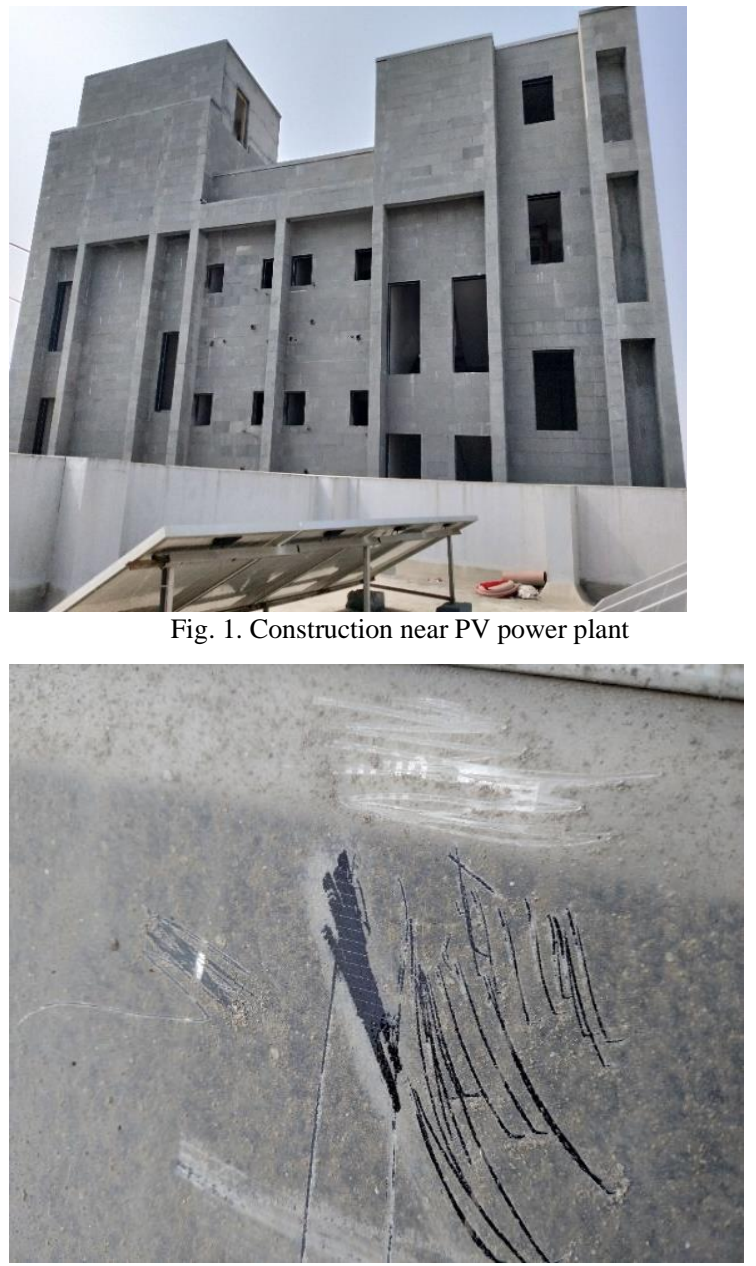

Fig. 2. Hardened cement on solar panel

At the site there is construction of 5 storey building. The building is on West side of solar plant and about 7 meter apart. Thus cement particle size is 3-100 microns, hence it gets easily carried away by wind. The surface of panel is rugged thus deposition of particle becomes permanent after it is allowed to settle over a period of time.

\section{B. Effect of Shadowing}

The cause of the hot spot could be a variety of cell failures, including partial shadowing. When a cell is shadowed, it could operate in reverse mode in which the cell 
consumes energy instead of generating it. shaded cell can overheat, and damage can occur in the cell or module. This can be considered a defect in the PV module[2]. The study revealed the impact of cement particles to be the most significant, with a $73 \mathrm{~g} / \mathrm{m} 2$ deposition of cement dust resulting in an $80 \%$ drop in PV short-circuit voltage[3].

\section{SYSTEM PERFORMANCE}

The power output delivered by photovoltaic system highly depends on amount of irradiance, which reaches solar cells. Shading is divided into 2 categories, namely soft shading such as air pollution and hard shading due accumulation of dust particle. In our case it is Hard Shading and all solar cell were shaded by dust particle.

The effect was observed as low voltage appearing across PV terminal i.e. $100 \mathrm{~V}$.

\section{A. Experimental Setup}

\section{METHODOLOGY}

The plant was installed in 2015. It is a fixed structure facing magnetic south. The total capacity of $3 \mathrm{~kW}$ (DC) solar PV plant. MODERN solar polycrystalline cell panels of dimension $1645 * 995 * 42 \mathrm{~mm}$ total of 12 panel. Growatt 3000 Series inverter was used of capacity $3 \mathrm{~kW}(\mathrm{AC})$ was used. Efficiency of inverter is $97.6 \%$.

\section{B. Different methods used for cleaning \\ i. Pressure (water) spray \\ ii. Vinegar + water \\ iii. Washing soda +water \\ iv. $\quad 1 / 2$ cup of baking soda +1 gallon of water $+1 / 8$ cup of liquid dish wash detergent. \\ v. Shampoo + water}

By using above methods, we did not get satisfactory result, as this method are time consuming and requires too much hard work, so we decided to try different acidic solution for cleaning. Finally, we got better results from HCL solution.

\section{vi. HCL solution $(30 \% \mathrm{w} / \mathrm{w})$}

\section{Calculation}

- Total area: $19.64 \mathrm{~m} 2$

- Solar insolation for that month: $5.22 \mathrm{kWh} / \mathrm{m} 2 /$ day

- Panel efficiency after considering annual degradation: $245 \mathrm{~W}$

- Expected output: $12.5 \mathrm{kWh} /$ day

- Actual generation: $1.8 \mathrm{kWh} /$ day

Loss of power $(\%):=100-\left(\frac{1.8}{12.5}\right) * 100$

$$
=85.6 \%
$$

\section{Duration of experiment}

Reading of 3 consecutive days before and after cleaning the panels were taken. To observe the effect of acid on ARC coating we observed the panel for 6 months. The panel during this period were cleaned as schedule without use acid or any other cleaning agent.

\section{E. Data Collection}

To compare and evaluate energy and power output between cleaned and cement deposited panel data collected for three consecutive days.

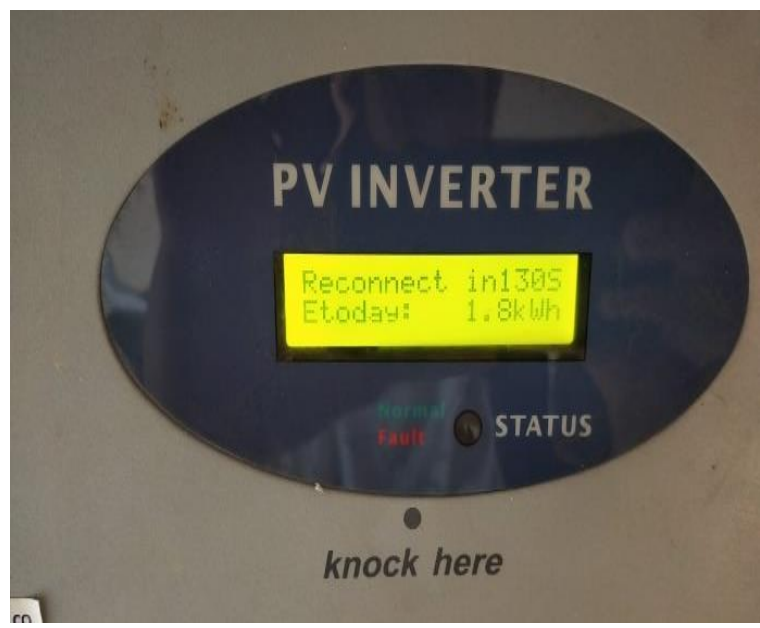

Fig. 3. Reading at end of day

TABLE 1: ELECTRIC UNIT GENERATION BEFORE CLEANING

\begin{tabular}{|c|c|}
\hline Date & kWh/Day \\
\hline 28 Nov. 2018 & 1.8 \\
\hline 29 Nov. 2018 & 1.8 \\
\hline 30 Nov. 2018 & 1.8 \\
\hline
\end{tabular}

Cleaning of panel included great care as no pressure can be applied or it will crack solar panel. The method used is same as acid etching concrete. Acid solution was $60 \%$ concentrated using it directly would have reacted with ARC and damaged it. To avoid any damage to ARC, solution was made with 1 part of acid mixed with 3 part of water. Chemical equations when diluted $\mathrm{HCl}$ react with cement are given below [6].

\section{i. $2 \mathrm{HCl}+\mathrm{Ca}(\mathrm{OH}) 2 \rightarrow \mathrm{CaCl} 2+2 \mathrm{H} 2 \mathrm{O}$ \\ ii. $\mathrm{CaCl} 2+3 \mathrm{CaO} \cdot \mathrm{Al} 2 \mathrm{O} 3+10 \mathrm{H} 2 \mathrm{O} \longrightarrow$ \\ 3CaO.Al2O3. $\mathrm{CaCl} 2.10 \mathrm{H} 2$}

The above reaction is exothermic and releases fumes.

Now we discuss about the scrub time, the scrub was kept as short as possible. Hence as solution was poured it was allowed to react and scrubbing would follow immediately. Care was taken of not using metal scrubber hence non scratcher sponge were to clean the panel After thoroughly cleaning using solution. The panel were washed again with clean water to remove and other residue present. The total time required was 40-man hour. 


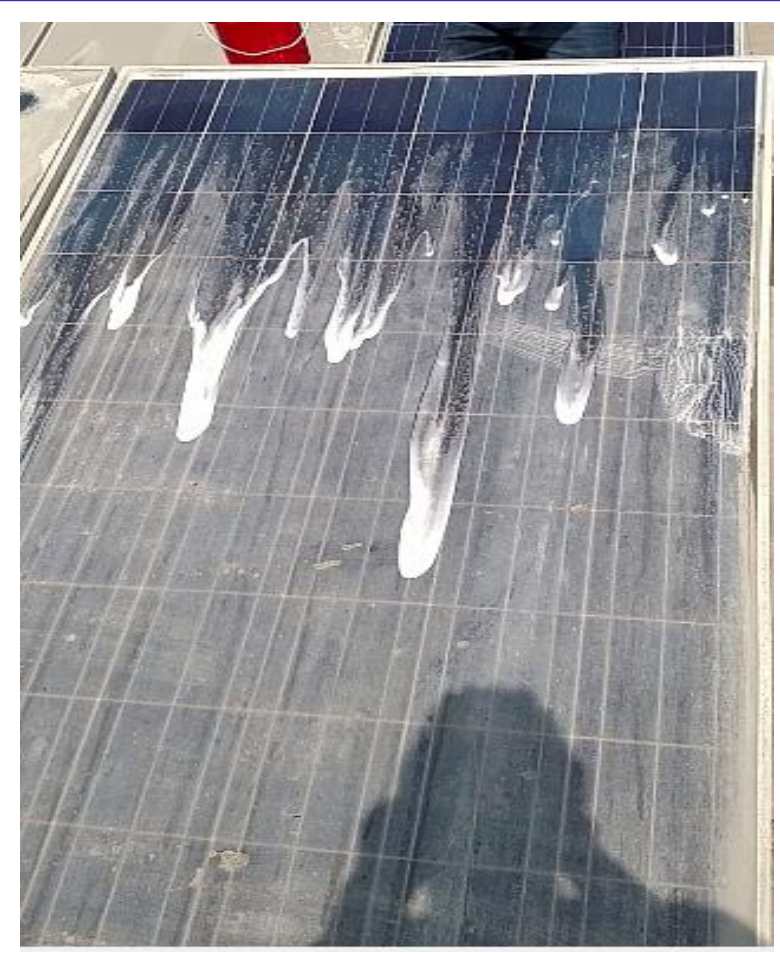

Fig. 4. Foam created due chemical reaction

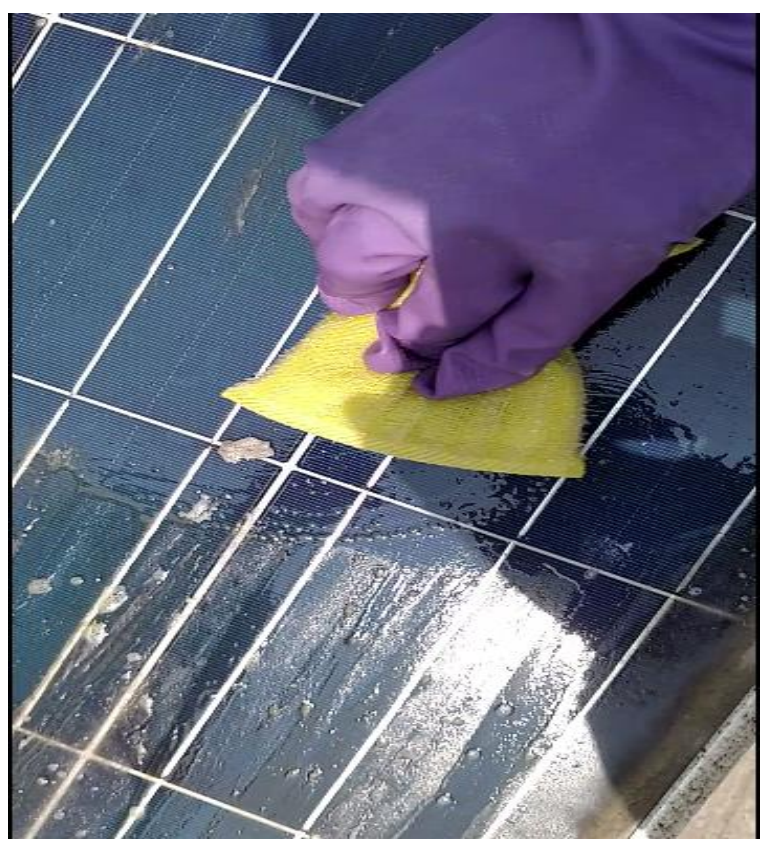

Fig. 5. Cement dropping

There were few panel on which cement particle bonded together and made Cement Droppings. This dropping act as shadow for single cell, but reduces the electricity output of whole panel. Thus creating a hotspot which increase the temperature of panel. These stain were hard to remove and can only be removed by using acid.
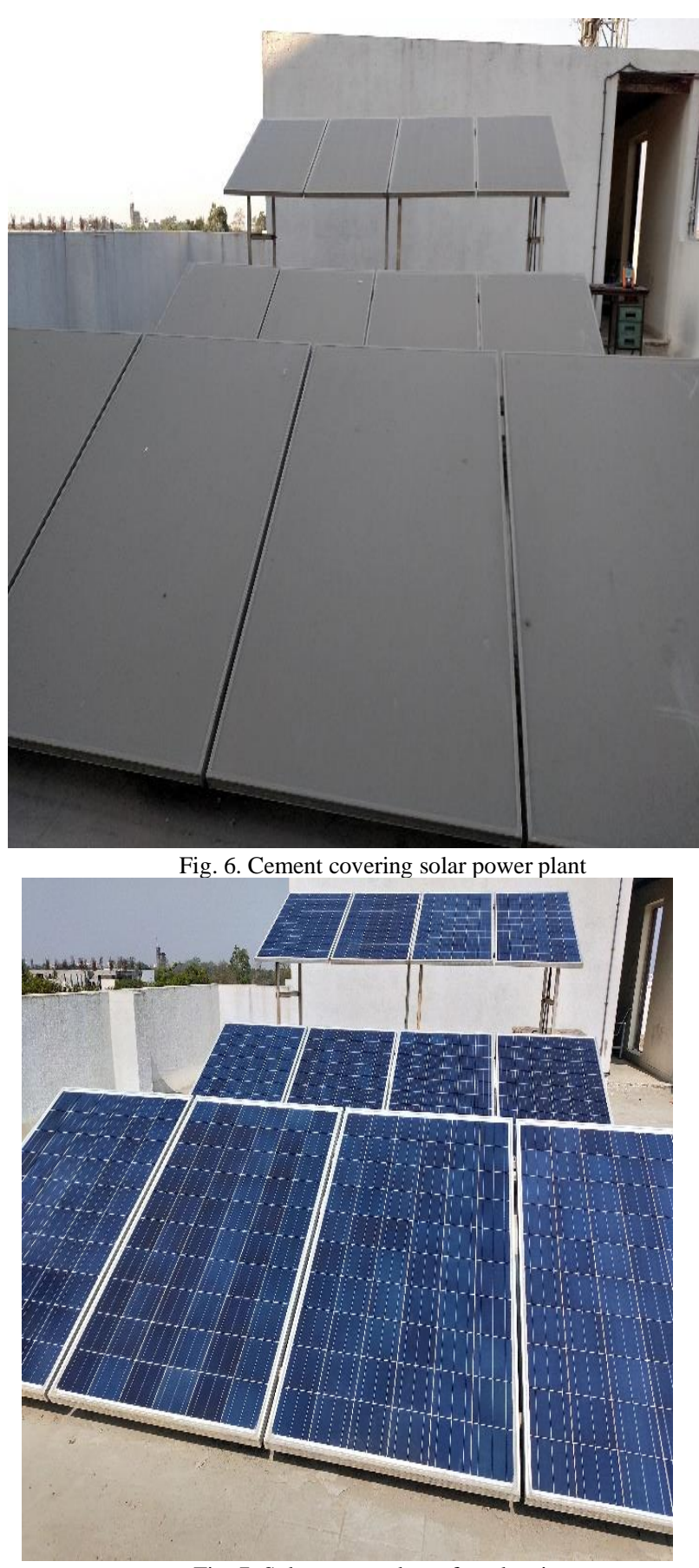

Fig. 7. Solar power plant after cleaning

\section{CONCLUSION}

After cleaning of panel following reading were observed TABLE 2 : ELECTRIC UNIT GENERATION AFTER CLEANING

\begin{tabular}{|c|c|}
\hline Date & kWh/Day \\
\hline 06 Dec. 2018 & 10.4 \\
\hline 07 Dec. 2018 & 7.8 \\
\hline 08 Dec. 2018 & 8.9 \\
\hline
\end{tabular}




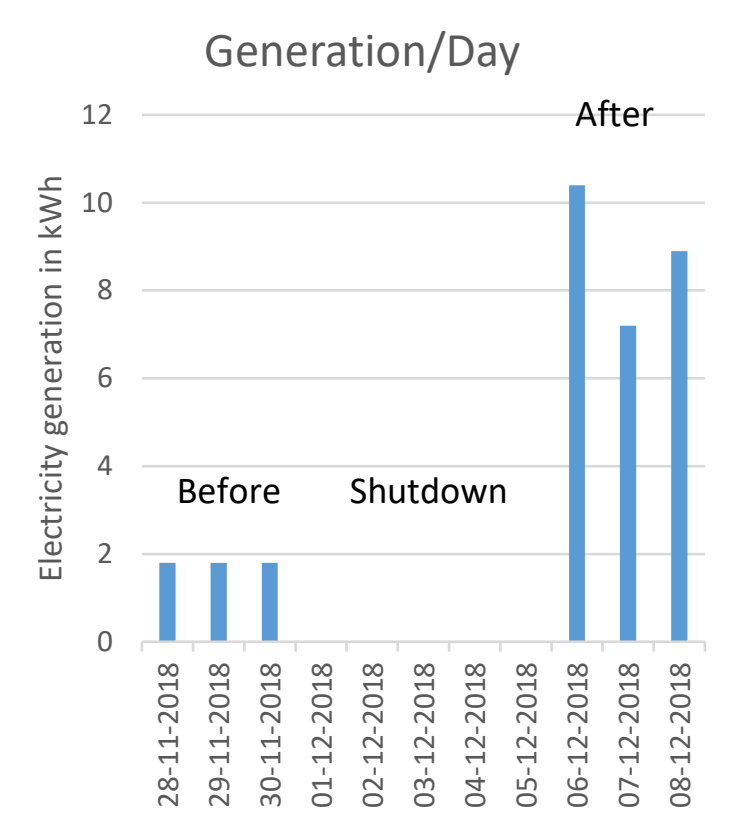

Fig. 8. Graph comparing performance before and after O\&M

The main concern was after effect of acid on panel component like aluminum casing. After 6 months of inspection, the panel are working as new ones. There are no yellow patches formed which occur due to damaged ARC. Aluminum is damaged due to acid. Hence it is advised to only use acid when above condition of cement deposition occur and not to use on regular $\mathrm{O} \& \mathrm{M}$.

Hard water used for cleaning of panel can accumulate over a period of time and cause scaling. This scaling cause reduction in electricity generation and become hotspots. This scaling can also be removed by acidic solution.

\section{REFERENCES}

[1] www.greenprospectsasia.com/content/malaysia-invest-solardevelopers

[2] M.A. Munoz, M.C. Alonso-Garc1', Nieves Vela, F. Chenlo "Early degradation of silicon PV modules and guaranty conditions" doi:10.1016/j.solener.2011.06.011

[3] B. Madhusudhana Reddy, H Sudarsana Rao, M.P George "Effect of Hydrochloric Acid ( $\mathrm{HCl}$ ) on Blended Cement (Fly Ash based) and Silica Fume Blended Cement and their Concretes" International Journal of Science and Technology Volume 1 No. 9, September, 2012

[4] Michael G. Deceglie, Matthew Muller, Zoe Defreitas and Sarah Kurtz "A Scalable Method for Extracting Soiling Rates from PV Production Data" Presented at the 43rd IEEE Photovoltaic Specialists Conference Portland, Oregon June 5-10, 2016

[5] J.L. Brady, L.L. Gantt, D.M. Fife, and D.A. Rich, ARCO Alaska Inc. S.W. Almond, Halliburton Services; and D.A. Ross "Cement Solubility in Acids" SPE 18986

[6] M.Catelani,L.Ciani1,L.Cristaldi, M. Faifer, M. Lazzaroni, M. Rossi "Characterization Of Photovoltaic Panels: The Effects Of Dust" 2nd IEEE ENERGYCON Conference \& Exhibition 2012/ Advances in Energy Conversion Symp

[7] Bing Guo, W. Javed, B. W. Figgis and T. Mirza "Effect of Dust and Weather Conditions on Photovoltaic Performance in Doha, Qatar" 9781-4673-6765-3/15/\$31.00 @2015 IEEE

[8] Dayal Singh Rajput, K. Sudhakar "Effect Of Dust On The Performance Of Solar PV Panel" ICGSEE-2013[14th - 16th March 2013] International Conference on Global Scenario in Environment and Energy
[9] Shaharin A. Sulaiman, Haizatul H. Hussain, Nik Siti H. Nik Leh, and Mohd S. I. Razali "Effects of Dust on the Performance of PV Panels" World Academy of Science, Engineering and Technology International Journal of Mechanical and Mechatronics Engineering Vol:5, No:10, 2011

[10] Vinay Gupta "Impact of Dust Deposition on Solar Photovoltaic Panel in Desert Region: Review" International Journal of Electronics, Electrical and Computational System IJEECS ISSN 2348-117X Volume 6, Issue 1 January 2017

[11] Mohammadreza Maghami, Hashim Hizam, Chandima Gomes "Impact of Dust on Solar Energy Generation based on Actual Performance" 2014 IEEE International Conference Power \& Energy (PENCON)

[12] Monto Mani, Rohit Pillai "Impact of dust on solar photovoltaic (PV) performance: Research status, challenges and recommendations" doi:10.1016/j.rser.2010.07.065

[13] Shaharin Anwar Sulaimana, Atul Kumar Singh, Mior Maarof Mior Mokhtara,

[14] Mohammed A. Bou-Rabeec, "Influence of Dirt Accumulation on Performance of PV Panels" doi: 10.1016/j.egypro.2014.06.00 